Jurnal Cendekia Akuntansi

Volume 2, Nomor 1

Kediri, Juni 2021

\title{
ANALISIS PENGARUH PELUNCURAN SISTEM E-MONEY DAN JUMLAH UANG BEREDAR TERHADAP INFLASI DI INDONESIA
}

\author{
Kalam Kalbuadi \\ Merlyana Dwinda Yanthi \\ Universitas Negeri Surabaya \\ E-Mail: Kalam.17080694056@mhs.unesa.ac.id
}

\begin{abstract}
Abstrak
Kemajuan teknologi memiliki kontribusi penuh di berbagai bidang termasuk ekonmi yang menciptakan uang elektronik (e-money). Tujuan penelitian ini adalah untuk mengetahui pengaruh variabel Jumlah Uang Beredar (JUB), dan $e$ - money terhadap inflasi di Indonesia. Data yang digunakan merupakan data sekunder yang diakses dari website Bank Indonesia dan juga Badan Pusat Statistik. Populasi dalam penelitian adalah inflasi, JUB, dan e-money. Hasil penelitian ini menunjukkan bahwa secara parsial hubungan antara JUB dan e-money terhadap inflasi memiliki pengaruh yang signifikan. E-money terhadap inflasi tidak berpengaruh signifikan, sedangkan JUB mempunyai pengaruh yang signifikan terhadap inflasi di Indonesia. Implikasi singkat penelitian ini diharapkan dapat membantu otoritas moneter dalam menstabilkan laju inflasi. Pengendalian inflasi tidak hanya dilakukan dari sisi kebijakan moneter tetapi secara simultan juga melalui kebijakan fiskal
\end{abstract}

\section{Kata kunci : e-money, JUB , dan Inflasi}

\begin{abstract}
Technological advances have a full contribution in various fields, including economics that create electronic money (e-money). The purpose of this study was to determine the effect of the variable amount of currency in circulation (CC) and e-money on inflation in Indonesia. The data used is secondary data accessed from the website of Bank Indonesia and Statistics Indonesia. Variables that used in this study are inflation, $C C$, and e-money. The results of this study indicate that partially the relationship between $C C$ and e-money on inflation has a significant effect. The brief implication of this research is expected to assist the monetary authority in stabilizing the inflation rate. Inflation control is not only carried out in terms of monetary policy but also simultaneously through fiscal policy
\end{abstract}

Kata kunci : E-money, CC, and Inflation 


\section{PENDAHULUAN}

Perkembangan globalisasi mengalami kemajuan teknologi yang sangat pesat dan salah satu pengaruh nya adalah pada sistem pembayaran, sehingga masyakakat dapat melakukan sistem transaksi tanpa menggunakan uang kartal. Dengan berkembangnya teknologi yang semakin maju, alat pembayaran terus mengalami perkembangan dari alat pembayaran tunai menjadi alat pembayaran nontunai (non-cash). Sistem pembayaran nontunai (non-cash) terdiri dari berbagai basis, mulai dari transaksi berbasis kartu sampai berbasis jaringan elektronik. Dalam perkembangannya, produk alat pembayaran nontunai berbasis kartu dan jaringan elektronik, memiliki karakteristik yang berbeda. Sistem pembayaran nontunai berbasis jaringan elektronik dikenal juga sebagai uang elektronik atau elektronic money (e-money).

Di Indonesia, e-money berpotensi untuk menggantikan peran dari uang tunai dalam pembayaran transaksi ritel. Dalam Peraturan Bank Indonesia No. 7/52/PBI/2005, yang termasuk dalam uang elektronik adalah Alat Pembayaran Menggunakan Kartu (APMK), yaitu kartu kredit, kartu debit, dan kartu ATM.

Penggunaan e-money sebagai alat pembayaran ini telah menguntungkan berbagai pihak, termasuk konsumen yang dapat melakukan pembayaran dengan lebih efektif, dan efisien. Secara khusus, penggunaan e-money ini juga memberikan keuntungan terutama untuk pembayaran mikro dan ritel. Penerbitan e-money ini dapat bertindak sebagai faktor yang dapat mengubah fungsi permintaan uang dan mengurangi jumlah uang kartal yang beredar.

Dengan beredarnya e-money, peredaran mata uang akan semakin diprivatisasi. Hal ini disebabkan karena dominasi uang negara akan menjadi terancam dengan beredarnya e-money (sistem pembayaran non-cash). Oleh sebab itu, pemerintah dalam hal ini secara khusus akan memiliki sedikit pilihan dalam menerapkan kebijakan jika ingin melanjutkan tanggung jawab atas kinerja ekonomi makro yang telah dan akan mereka selesaikan, kecuali jika pemerintah ingin mencari instrumen kebijakan baru yang akan mereka terapkan di Indonesia.

Jumlah uang beredar merupakan unsur yang cukup signifikan terhadap keadaan perekonomian suatu negara yaitu hubungannya dengan tingkat inflasi. Perubahan jumlah uang beredar ditentukan oleh hasil interaksi antara masyarakat, lembaga keuangan, serta bank sentral (Tambunan, 2012).

Dilihat dari data yang diambil Bank Indonesia yang dapat diunduh di bi.go.id, dapat ditinjau bahwa dampak dari beredarnya sistem e-money cukup mempengaruhi tingkat inflasi, dilihat dari data statistik yang tersedia bahwa penurunan tingkat inflasi menurun secara signifikan dimulai dari bulan Mei 2019 dengan tingkat inflasi 3,32\% menjadi $1,42 \%$ di bulan September 2020. Berdasarkan data statistik Bank Indonesia (BI) tahun 2019, dengan pertumbuhan nominal $216,46 \%$, volume transaksi uang elektronik juga meningkat $157,31 \%$ menjadi 330,67 juta transaksi dari November 2017 yang mencapai 128,51 juta transaksi.

Kenaikan volume dan nilai transaksi uang elektronik tersebut, tidak lepas dari meningkatnya jumlah uang yang beredar di masyarakat. jumlah uang elektronik yang beredar tercatat sebanyak 152,07 juta atau meningkat 33,72\% pada November 2018 dibandingkan dengan periode sama tahun sebelumnya yang 
sebanyak 113,72 juta. Dari peningkatan yang cukup signifikan tersebut maka dapat diambil garis lurus bahwa perlunya analisis dalam mengukur seberapa besar pengaruh penggunaan e-money. terhadap menurunya tingkat inflasi di Indonesia pada tahun 2019 sampai dengan 2020 sehingga masuk ke dalam pembahasan pada judul penelitian yang diambil oleh penulis, yaitu Analisis pengaruh peluncuran sistem e-money dan jumlah uang beredar terhadap inflasi di Indonesia dalam kurun waktu 2015- 2020 dengan data sebagai berikut :

Tabel 1

Presentase jumlah e-money, JUB (M1)

dan Inflasi tahun 2015- 2020

\begin{tabular}{|c|c|c|c|}
\hline Tahun & $\begin{array}{c}\text { Emoney } \\
(\%)\end{array}$ & $\begin{array}{c}\text { JUB } \\
(\%)\end{array}$ & $\begin{array}{c}\text { Inflasi } \\
(\%)\end{array}$ \\
\hline 2015 & 3.22 & 12.41 & 3.35 \\
\hline 2016 & 4.80 & 14.55 & 3.02 \\
\hline 2017 & 8.43 & 16.35 & 3.61 \\
\hline 2018 & 15.67 & 17.13 & 3.13 \\
\hline 2019 & 27.39 & 18.40 & 2.72 \\
\hline 2020 & 40.50 & 21.15 & 1.68 \\
\hline
\end{tabular}

\section{TINJAUAN PUSTAKA}

\section{Teori Kuantitas}

Teori yang dikemukakan oleh Irving Fisher yang menyatakan bahwa inflasi disebabkan oleh jumlah beredarnya uang, dengan asumsi kecepatan perputaran uang dan volume barang yang diperdagangkan tetap.

\section{Teori Keynes}

Keynes mengungkapkan bahwa jumlah beredarnya uang bukan satu- satunya penyebab inflasi. Menurut teori ini inflasi disebabkan karena masyarakat ingin hidup diluar batas dari kemampuan ekonomisnya (Sinaungan, 1995). Mengacu pada teori kuantitas, Keynes memiliki pendapat bahwa kecepatan perputaran uang sangat fluktuatif atau berubah-ubah. Apabila terjadi penambahan pada jumlah uang yang beredar maka transaksi yang terjadi di masyarakat akan meningkat. Fenomena tersebut yang kemudian akan meningkatkan permintaan output dari masyarakat. Ketidakmampuan penawaran output untuk memenuhi permintaan tersebut yang akan memicu timbulnya inflasi. Pendapat yang sama dijelaskan oleh Milton Friedman dalam teori kuantitas modern. Menurut Friedman perputaran uang dipengaruhi oleh berbagai faktor. Berbagai macam faktor tersebut di antaranya yaitu: penghasilan dari obligasi dan saham, tingkat harga umum, inflasi, teknologi dan transportasi, serta perbandingan kesejahteraan antara manusia (Sinaungan, 1995). 


\section{Inflasi}

Menurut Boediono (1995) inflasi adalah kecenderungan dari harga-harga untuk menaik secara menyeluruh dan terus menerus. Kenaikan harga dari satu atau dua barang saja tidak disebut inflasi, kecuali bila kenaikan tersebut meluas atau mengakibatkan kenaikan pada sebagian besar harga barang-barang lain yaitu harga makanan, harga makanan jadi, minuman, rokok, dan tembakau, harga sandang, harga kesehatan, harga pendidikan, rekreasi, dan olahraga, harga transportasi, komunikasi, dan jasa keuangan. Dari definisi tersebut, ada tiga komponen yang harus dipenuhi agar dapat dikatakan terjadi inflasi, yaitu:

1. Kenaikan harga, yaitu apabila harga suatu komoditas menjadi lebih tinggi dari harga periode sebelumnya.

2. Bersifat umum, yaitu kenaikan harga komoditas secara umum yang dikonsumsi masyarakat bukan merupakan kenaikan suatu komoditas yang tidak menyebabkan harga naik secara umum.

3. Berlangsung terus menerus, kenaikan harga yang bersifat umum juga belum akan memunculkan inflasi, jika terjadi sesaat misalnya kenaikan harga pada saat lebaran atau tahun baru bukan merupakan inflasi. Kebalikan dari inflasi adalah deflasi. Deflasi adalah suatu keadaan dimana jumlah barang yang beredar melebihi jumlah uang yang beredar sehingga harga barang-barang menjadi turun, dan nilai uang menjadi naik.

\section{Definisi Jumlah Uang Beredar}

Di dalam membahas mengenai uang yang terdapat dalam perekonomian sangat penting untuk membedakan diantara mata uang dalam peredaran dan uang beredar. Mata uang dalam peredaran adalah seluruh jumlah uang yang telah dikeluarkan dan diedarkan oleh Bank Sentral. Mata uang tersebut terdiri dari dua jenis yaitu uang logam dan uang kertas. Dengan demikian mata uang dalam peredaran sama dengan uang kartal. Sedangkan uang beredar adalah semua jenis uang yang ada di dalam perekonomian yaitu jumlah dari mata uang dalam peredaran ditambah dengan uang giral dalam bank-bank umum. Uang beredar atau money supply dibedakan menjadi dua pengertian yaitu dalam arti sempit dan arti luas.

\section{Uang Beredar Dalam Arti Sempit (M1)}

Uang beredar dalam arti sempit (M1) didefinisikan sebagai uang kartal ditambah dengan uang giral (currency plus demand deposits).

\section{M1 $=\mathbf{C}+\mathbf{D D}$}

Penjelasan:

M1 = Jumlah uang beredar dalam arti sempit

$\mathrm{C} \quad=$ Currency (uang cartal)

DD = Demand Deposits (uang giral)

Uang giral (DD) di sini hanya mencakup saldo rekening koran/ giro milik masyarakat umum yang disimpan di bank. Sedangkan saldo rekening koran milik bank pada bank lain atau bank sentral (Bank Indonesia) ataupun saldo rekening koran milik pemerintah pada bank atau bank sentral tidak dimasukan dalam definisi DD. Satu hal lagi yang penting untuk dicatat mengenai DD ini adalah bahwa yang dimaksud disini adalah saldo atau uang milik masyarakat yang masih ada di bank dan belum digunakan pemiliknya untuk membayar/ berbelanja. 
Pengertian jumlah uang beredar dalam arti sempit (M1) bahwa uang beredar adalah daya beli yang langsung bisa digunakan untuk pembayaran, bisa diperluas dan mencakup alat-alat pembayaran yang "mendekati" uang, misalnya deposito berjangka (time deposits) dan simpanan tabungan (saving deposits) pada bank-bank. Uang yang disimpan dalam bentuk deposito berjangka dan tabungan ini sebenarnya adalah juga adalah daya beli potensial bagi pemiliknya, meskipun tidak semudah uang tunai atau cek untuk menggunakannya (Boediono, 1995).

\section{Definisi Uang Elektronik}

Uang elektronik menurut Peraturan Bank Indonesia No.20/6/PBI/2018 tentang uang elektronik adalah instrumen pembayaran yang memenuhi unsur sebagai berikut:

1) Diterbitkan atas dasar nilai uang yang disetor terlebih dahulu kepada penerbit.

2) Nilai uang disimpan secara elektronik dalam suatu media server atau chip.

3) Nilai uang elektronik yang dikelola oleh penerbit bukan merupakan simpanan sebagaimana dimaksud dalam Undang- undang yang mengatur mengenai perbankan.

\section{Penelitian Terdahulu}

Dalam rangka menunjang penelitian ini, penulis mengambil beberapa studi terdahulu sebagai bahan referensi dan untuk membantu penulis dalam pengerjaan penelitian. Studi terdahulu pertama adalah penelitian yang dilakukan oleh Sapitri(2017) yang berjudul "Pengaruh Jumlah Uang Beredar Terhadap Inflasi di Indonesia Tahun 2013-2016". Dalam skripsi tersebut dijelaskan bahwa peningkatan inflasi dapat ditinjau melalui meningkatnya jumlah uang beredar, sehingga apabila Bank Indonesia mengeluarkan kebijakan moneter ekspansif yaitu dengan menambah Jumlah uang beredar dengan jumlah tertentu, maka tingkat inflasi akan meningkat seiring dengan presentase JUB di keluarkan.

Penelitian selanjutnya dilakukan oleh Fauzi \& Istanto (2013) yang berjudul "Analisis Dampak Pembayaran Non Tunai Terhadap Jumlah Uang Beredar Di Indonesia". Penelitian ini memiliki hasil bahwa e-money memiliki pengaruh positif signifikan terhadap jumlah uang beredar. Hasil penelitian akan menunjukan positif jika menggunakan variabel jangka pendek yang harus menggunakan indikator nilai transaksi uang elektronik, dan jika menggunakan jangka Panjang, variabel harus menggunakan indikator volume transaksi uang elektronik. Penelitian ini menggunakan metode Johansen Cointegration Test dan Error Correction Model (ECM)

Studi terdahulu ketiga yang digunakan dalam penelitian ini adalah jurnal berjudul Lifting The Barriers to E-commerce in ASEAN oleh A.T. Kearney dalam CIMB ASEAN Research Institute tahun 2015. Dalam jurnal tersebut dijelaskan bahwa e-commerce di kawasan Asia Tenggara masih terbelakang terhitung kurang dari satu persen dari total penjualan retail dibandingkan dengan tingkat enam sampai delapan persen di Eropa, China, dan Amerika Serikat. Di tahun-tahun mendatang seiring meningkatnya daya beli, penetrasi internet menyebar, dan penawaran online membaik, retail online di pasar ASEAN bisa tumbuh sebanyak $25 \%$ per tahun. 
Dalam beberapa kajian di atas, bentuk penelitian yang mengangkat topik e-commerce maupun pertumbuhan ekonomi di Indonesia. Oleh karenanya fokus kajian penulis mengenai pertumbuhan ekonomi kelas menengah terhadap perkembangan e-commerce, belum pernah dijumpai skripsi dengan topik seperti yang penulis tulis. Dengan demikian penelitian ini layak untuk diteliti dalam rangka pengembangan penelitian.

Penelitian Gintting et al., (2019) yang berjudul "dampak transaksi non tunai terhadap perputaran uang di Indonesia. Penelitian ini menggunakan metode Regresi Linear Berganda dengan menggunakan OLS (Ordinary Least Square). Secara parsial, Variabel e-money tidak berpengaruh terhadap velocity of money

Penelitian Fatmawati \& Yuliana (2019) dengan judul "Pengaruh Transaksi Non Tunai Terhadap Jumlah Uang Beredar Di Indonesia Tahun 2015- 2018 Dengan Inflasi Sebagai Variabel Moderasi”. Penelitian tersebut menggunakan metode penelitian regresi berganda. Secara parsial, inflasi berpengaruh positif signifikan terhadap jumlah uang yang telah beredar. Hal ini dikarenakan inflasi akan menimbulkan gangguan terhadap nilai dan fungsi uang. Peningkatan inflasi akan meningkatkan kecenderungan belanja, yang selanjutnya akan membuat jumlah uang beredar yang ada di masyarakat juga terus meningkat.

Penelitian Igamo \& Falianty T, (2018) dengan judul "The Impact of Electronic Money on the Efficiency of The Payment System and The Substitution of Cash In Indonesia". Penelitian tersebut menggunakan Data analysis using Vector Regression (VAR) untuk menganalisis data. Hasil dari penelitian ini menunjukan bahwa penggunaan e-money berdampak negative signifikan terhadap M1(Jumlah uang yang beredar). Hasil ini dikarenakan masyarakat dapat merasakan banyak manfaat dari uang elektronk sehingga memberikan ketertarikan dalam penggunaan E-money dan telah menjadi salah satu gaya hidup dalam kegiatan ekonomi. Statistik juga menunjukkan bahwa nilai transaksi e-money terus meningkat dari beberapa tahun sebelumnya sehingga memperkuat potensi uang elektronik untuk mengurangi pertumbuhan uang tunai yang ada di Indonesia.

Penelitian Hong (2009) dengan judul "The Impact of E-money on the Economy". Hasil penelitian menunjukan bahwa uang elektronik berdampak kecil terhadap jumlah uang yang beredar. Karena menurut Hong (2009) yang mempengaruhi jumlah uang beredar adalah e-money dan currency, tetapi currency memiliki dampak yang lebih signifikan

\section{Kerangka Konseptual}

Kerangka konseptual dibuat dengan mempertimbangkan uraian yang telah dipaparkan sebelumnya, pada bagian ini akan diuraikan beberapa komponen yang dijadikan peneliti sebagai sebuah landasan berpikir dari penelitian yang akan dilakukan. Landasan yang dimaksud akan lebih mengarahkan peneliti untuk menemukan data dan informasi dalam penelitian ini untuk memecahkan masalah yang telah dipaparkan sebelumnya.

Bank Indonesia sebagai lembaga yang mengambil kebijakan moneter, melihat perkembangan teknologi dan kebutuhan masyarakat yang semakin berkembang, Bank Indonesia memberikan perizinan bagi perbankan maupun lembaga bukan bank untuk menerbitkan Uang Elektronik (e-money). Uang elektronik dapat digunakan untuk kegiatan transaksi yang memungkinkan 
Pemiliknya untuk melakukan pembayaran atas transaksi tanpa menggunakan uang tunai. Penerbitan Uang Elektronik semakin berkembang semenjak tahun terbitnya hingga kini. Perubahan Permintaan Uang dapat diasumsikan memiliki hubungan pada Jumlah Uang Beredar dalam arti sempit (M1), Velocity of Money (V), Pendapatan Per Kapita, dan EDC (Electronic Data Capture) yang ada di Indonesia.

\section{Perumusan Hipotesis}

Hipotesis merupakan sebuah prediksi sementara terhadap rumusan masalah penelitian, dimana rumusan masalah telah di nyatakan dalam bentuk kalimat penelitian. Dikatakan sementara, karena jawaban yang di berikan berdasarkan pada teori yang relevan, belum didasarkan pada fakta - fakta empiris yang diperoleh melalui pengumpulan data. Jadi hipotesis juga dapat dinyatakan sebagai jawaban teoritis terhadap rumusan masalah penelitian.

Menurut Lintangsari et al., (2018) mengatakan bahwa terdapat istilah float yang ada pada sistem e-money, yang artinya terdapat sejumlah dana yang dimiliki penerbit (issuer) yang masih tersimpan dalam bentuk elektronik dan belum ditagihkan oleh merchant / belum digunakan untuk transaksi ataupun pembayaran. Dan sesuai dengan pendapat (Lintangsari et al., 2018) yang mengtakan bahwa jumlah uang beredar dalam arti luas (M2) tidak dapat dirubah oleh e-money, tetapi e-money dalam bentuk float dapat menyebabkan pergeseran dari uang kuasi menjadi JUB dalam arti sempit (M1)

Dari tinjauan pustaka yang telah penulis uraikan diatas dan berdasarkan referensi penelitian terdahulu maka hipotesis penelitian dirumuskan sebagai berikut:

1. Diduga Variabel e-money memiliki pengaruh positif signifikan terhadap variabel inflasi.

2. Diduga Variabel Jumlah Uang beredar mampu memberikan pengaruh terhadap variabel Inflasi.

\section{METODE PENELITIAN}

\section{Jenis Penelitian}

Penelitian ini merupakan penelitian eksplanatory. Menurut Rini (2017:52) Penelitian Eksplanatory merupakan proses penelitian untuk menemukan sifat alamiah dari permasalahan dan variabel terkait. Maksud dari Pernyataan diatas adalah jenis penelitian ini menguji pengaruh antara variabel $X$ (terikat) terhadap variabel Y (bebas)

\section{Rancangan Penelitian}

Rancangan dalam penelitian ini digunakan agar penelitian berjalan dengan baik dan data yang akan diperoleh sesuai dengan harapan. Penelitian ini dilakukan untuk mengetahui apakah terdapat pengaruh dari indikasi E-money dan juga jumlah uang beredar terhadap Inflasi di Indonesia 


\section{Ruang Lingkup dan Objek Penelitian}

Ruang lingkup penelitian ini meliputi data Jumlah Perhitungan Inflasi, Jumlah Uang Beredar, dan peredaran e-money di Indonesia. Data dalam kurun waktu dalam penelitian ini dari tahun 2015-2020.

\section{Metode Pengumpulan Data}

Metode Pengumpulan data pada penelitin ini adalah metode dokumentasi dan penelitian kepustakaan, yaitu Teknik pengumpulan data yang diperlukan dengan cara membaca buku dan literatur lainya baik yang dianjurkan maupun yang diwajibkan dan sesuai dengan penelitian yang dibahas. Sumber data yang diambil berasal dari website bi.go.id dan juga BPS (Badan Pusat Statistik) yang dapat diakses di www.bps.go.id.

Tabel 2

Pengumpulan Data

\begin{tabular}{|l|l|}
\hline \multicolumn{1}{|c|}{ Variabel } & \multicolumn{1}{|c|}{ Indikator } \\
\hline E-Money (X1) & $\begin{array}{l}\text { Indikator dilihat dari data volume transaksi } \\
\text { uang elektronik dalam periode tertentu yang } \\
\text { dapat diakses di situs resmi www.bi.go.id }\end{array}$ \\
\hline Jumlah Uang Beredar (X2) & $\begin{array}{l}\text { Indikator dapat dilihat dari data Jumlah Uang } \\
\text { Beredar yang dapat diakses di situs resmi dari } \\
\text { BPS (Biro Pusat Statistik www.bps.go.id }\end{array}$ \\
\hline Inflasi (Y) & $\begin{array}{l}\text { Indikator dapat diakses di situs resmi bi pada } \\
\text { data inflasi di www.bi.go.id }\end{array}$ \\
\hline
\end{tabular}

\section{Metode Pengumpulan Data}

Metode Pengumpulan data pada penelitin ini adalah metode dokumentasi yaitu mengumpulkan data sekunder berupa merekap data dari Badan Pusat Statistik dan situs resmi pada Bank Indonesia

\section{HASIL PENELITIAN DAN PEMBAHASAN}

Uji data dalam penelitian kali ini menggunakan analisis deskriptif kuantitatif dengan metode regresi linier berganda. Desktriptif Kuantitatif adalah jenis penelitian yang digunakan untuk analisis data dengan cara mendeskripsikan atau menggambarkan data yang telah terkumpul sebagaimana adanya. Penggunaan metode regresi linier berganda adalah untuk mengetahui seberapa besar pengaruh variabel bebas terhadap variabel terikat baik secara parsial maupun stimultan.

Berdasarkan hasil dari perhitungan regresi linier sederhana yang telah dilakukan sebelumnya dapat diketahui bahwa variabel e-money berpengaruh positif terhadap JUB dengan signifikansi $0,005<0,05$. hasil hipotesis tersebut 
dapat menjelaskan bahwa semakin tinggi tingkat penggunaan e-money dapat meningkatkan jumlah uang beredar sehingga $\mathrm{H} 1$ diterima

Model analisis data dengan menggunakan model regresi linear berganda yang diolah melalui program SPSS versi 25 dengan hasil akhir yang diperoleh dari penelitian sebagai berikut:

Tabel 4

Uji Statistik Deskriptif

\begin{tabular}{|l|c|c|c|c|c|}
\hline \multicolumn{6}{|c|}{ Descriptive Statistics } \\
\hline & $\mathrm{N}$ & Minimum & Maximum & Mean & Std. Deviation \\
\hline EMONEY & 6 & 3.22 & 40.50 & 16.6683 & 14.65254 \\
\hline JUB & 6 & 12.41 & 21.15 & 16.6650 & 3.03378 \\
\hline INFLASI & 6 & 1.68 & 3.61 & 2.9183 & .67715 \\
\hline
\end{tabular}

Berdasarkan hasil data dari spss tentang Pengaruh Peluncuran sistem Emoney terhadap jumlah uang beredar dan inflasi yaitu pada variabel E-money (X1) memiliki minimum sebesar 3.22, maximum sebesar 40.50 dan rata-rata atau mean sebesar 16.6683 dengan Std. Deviation sebesar 14.65254.Pada variabel Jumlah Uang Beredar (X2) memiliki nilai minimum 12.41, nilai maximum 21.15 dan mean atau rata-rata sebesar 16.6650 dengan Std. Deviation sebesar 3.03378 Sementara untuk Variabel Inflasi (X2) memiliki nilai minimum 1.68, nilai maximum sebesar 3.61 dan mean sebesar 2.9183 dengan Std. Deviation sebesar 0.67715 .

\section{Uji Normalitas}

Bila dilihat dari data hasil analisis Uji Normalitas pada penelitian ini menunjukkan nilai sebesar 0.125 atau lebih dari 0.05. Dapat di simpulkan bahwa data terdistribusi normal dan dapat ditinjau lebih lanjut.

\section{Uji Multikolinieritas}

Tabel 5

Uji Multikolinieritas

\begin{tabular}{|l|c|c|}
\hline \multirow{2}{*}{ Variabel Independen } & \multicolumn{2}{c|}{ Variabel Dependen } \\
\cline { 2 - 3 } & \multicolumn{2}{|c|}{ Inflasi } \\
\cline { 2 - 3 } & Tolerance & VIF \\
\hline EMONEY & 0,108 & 9,277 \\
\hline JUB & 0,108 & 9,277 \\
\hline
\end{tabular}

diketahui pada table diatas bahwa pada VIF memiliki nilai 9.277 yang lebih kecil dari nilai 10, maka model regresi dapat disimpulkan terbebas dari asumsi multikolinearitas. 


\section{Uji Heterokedastisitas}

Tabel 6

Uji Heterokedastisitas

\begin{tabular}{|l|c|c|}
\hline \multirow{2}{*}{ Variabel Independen } & \multicolumn{2}{|c|}{ Variabel Dependen } \\
\cline { 2 - 3 } & \multicolumn{2}{|c|}{ Inflasi } \\
\cline { 2 - 3 } & $\mathrm{B}$ & Sig. \\
\hline (Constant) & 1,867 & 0,439 \\
\hline EMONEY & $-0,67$ & 0,129 \\
\hline JUB & 0,130 & 0,046 \\
\hline
\end{tabular}

Gambar diatas merupakan gambar uji heteroskedastisitas dengan metode glejser. Dapat dilihat dari nilai Sig. Masing-masing variabel memiliki nilai Sig. yang lebih dari tingkat kepercayaan 5\% atau lebih besar atau sama dengan 0.05. Dapat disimpulkan bahwa tidak ada gejala Heteroskedastisitas dan data dinyatakan layak uji.

\section{Uji Autokorelasi}

Tabel 7

Uji Autokorelasi

\begin{tabular}{|c|c|c|c|}
\hline Model & R Squares & $\begin{array}{c}\text { Adjusted R } \\
\text { Square }\end{array}$ & $\begin{array}{c}\text { Std. Error of } \\
\text { the Estimate }\end{array}$ \\
\hline 1 & 0,843 & 0,739 & 0,34599 \\
\hline
\end{tabular}

Dapat dilihat bahwa untuk hasil Durbin-Watson (DW) sebesar 2.603, sedangkan untuk nilai DU dalam data ini yang telah di cocokkan dengan tabel DU adalah sebesar 2.2866. Sedangkan nilai 4-DU adalah 1.7134. Untuk tabel DL diketahui sebesar 0.3674 dan 4-DL sebesar 3.6326. Dapat disimpulkan bahwa 4-DU<D<4DL. Jadi keputusannya adalah tidak ada autokorelasi negatif dan tidak ada kesimpulan jadi data masih layak untuk diteliti.

\section{Uji T}

\begin{tabular}{|l|c|} 
Tabel 8 \\
Uji T \\
\begin{tabular}{|l|c|c|}
\hline \multirow{3}{*}{ Variabel Independen } & \multicolumn{2}{c|}{ Variabel Dependen } \\
\cline { 2 - 3 } & \multicolumn{2}{|c|}{ Inflasi } \\
\cline { 2 - 3 } \multicolumn{1}{c|}{} & $\mathrm{B}$ & Sig. \\
\hline (Constant) & 1,867 & 0,439 \\
\hline EMONEY & $-0,67$ & 0,129 \\
\hline JUB & 0,130 & 0,046 \\
\hline
\end{tabular}
\end{tabular}

Dapat dilihat pada gambar, pada nilai signifikansi untuk variabel emoney berada di atas nilai 0,05 sehingga dismpulkan tidak terdapat pengaruh terhadap variabel inflasi, sedangkan pada variabel JUB berada di bawah nilai kepercayaan yaitu 0,05, sehingga disimpulkan bahwa terdapat pengaruh terhadap variabel inflasi. 


\section{Uji F}

Tabel 9

Uji F

\begin{tabular}{|l|c|c|c|c|c|}
\hline \multicolumn{1}{|c|}{ Model } & $\begin{array}{c}\text { Sum of } \\
\text { Squares }\end{array}$ & df & $\begin{array}{c}\text { Mean } \\
\text { Square }\end{array}$ & F & Sig. \\
\hline Regression & 1,934 & 2 & 0,967 & 8,076 & $0,062^{\mathrm{b}}$ \\
\hline Residual & 0,359 & 3 & 0,120 & & \\
\hline Total & 2,293 & 5 & & & \\
\hline
\end{tabular}

Pada uji F dapat dilihat pada table diatas bahwa nilai Sig. berada pada $0,0062<$ daripada 0,05 . Keputusam dari uji $\mathrm{F}$ adalah tidak terdapat pengaruh variabel $\mathrm{X}$ secara simultan atau bersama-sama terhadap variabel $\mathrm{Y}$, tetapi terdapat pengaruh di salah satu variabel X.

\section{Koefisien Determinasi}

Tabel 10

Uji R-Square

\begin{tabular}{|c|c|c|c|}
\hline Model & R Squares & $\begin{array}{c}\text { Adjusted R } \\
\text { Square }\end{array}$ & $\begin{array}{c}\text { Durbin- } \\
\text { Watson }\end{array}$ \\
\hline 1 & 0,843 & 0,739 & 2,603 \\
\hline
\end{tabular}

Dapat dilihat pada gambar diatas, tingkat koefisien determinasi dapat dilihat dari besarnya tingakat $\mathrm{R}$ Square yaitu sebesar 0.843 sehingga dapat di tarik kesimpulan bahwa Variabel $\mathrm{X}$ yaitu sektor primer, sekunder berpengaruh terhadap secara simultan sebesar $84.3 \%$ dan $15.7 \%$ lainnya di pengaruhi oleh variabel lain di luar model regresi.

\section{Pembahasan:}

1. Pengaruh Peluncuran Sistem $\boldsymbol{E}$-Money terhadap Inflasi Di Indonesia Pada uji $\mathrm{F}$ dapat dilihat pada table diatas bahwa nilai Sig. berada pada 0,0062 < daripada 0,05. Keputusam dari uji $\mathrm{F}$ adalah tidak terdapat pengaruh variabel $\mathrm{X}$ secara simultan atau bersama-sama terhadap variabel $\mathrm{Y}$, tetapi terdapat pengaruh di salah satu variabel X. yang dapat diartikan salah satu nya tidak terdapat pengaruh terhadap variabel inflasi, yaitu pada variabel e-money. Dapat dilihat pada nilai signifikansi untuk variabel emoney berada di atas nilai 0,05 sehingga dismpulkan tidak terdapat pengaruh terhadap variabel inflasi

\section{Pengaruh Jumlah Uang Beredar terhadap Inflasi Di Indonesia}

Pada uji $F$ dapat dilihat pada table diatas bahwa nilai Sig. berada pada 0,0062 < daripada 0,05 . Keputusam dari uji $\mathrm{F}$ adalah tidak terdapat pengaruh variabel $\mathrm{X}$ secara simultan atau bersama-sama terhadap variabel $Y$, tetapi terdapat pengaruh di salah satu variabel $\mathrm{X}$. yang dapat diartikan salah satu nya tidak terdapat pengaruh terhadap variabel inflasi, yaitu pada variabel e-money. Dapat dilihat pada nilai signifikansi untuk variabel emoney berada di atas nilai 0,05 sehingga dismpulkan tidak terdapat pengaruh terhadap variabel inflasi

Hal ini sesuai dengan teori kuantitas yang dikemukakan oleh Irving Fisher yang menyatakan bahwa inflasi disebabkan oleh jumlah beredarnya uang, 
dengan asumsi kecepatan perputaran uang dan volume barang yang diperdagangkan tetap.

Berdasarkan asil dari penelitian ini menyatakan bahwa secara parsial hubungan antara JUB dan e-money terhadap inflasi memiliki pengaruh yang signifikan. Sesuai dengan hasil penelitian sebelumnya yaitu penelitian yang dilakukan oleh Widodo (2018) yang memiliki kesimpulan bahwa inflasi secara parsial memiliki pengaruh terhadap variabel2 yang telah ditentukan. Didukung oleh pendapat (Mahendra, 2016) yang berjudul "Analisis Pengaruh Jumlah Uang Beredar, Suku Bunga SBI dan Nilai Tukar Terhadap Inflasi di Indonesia“ yang menyatakan Pada masa krisis terutama tahun 1998, Indonesia mengalami inflasi tertinggi yaitu mencapai 77,6 \%. Peningkatan laju inflasi terutama disebabkan oleh depresiasi nilai tukar rupiah, krisis ekonomi dan ekspektasi terhadap inflasi yang tinggi. Sebelumnya Indonesia pernah mengalami hiper inflasi pada masa akhir orde lama yaitu pada tahun 1966. Sehingga secara psikologis inflasi merupakan krisis bagi masyarakat Indonesia. Akan tetapi, terdapat beberapa penelitian yang menghasilkan kesimpulan yang bertolakbelakang dengan hasil penelitian ini adalah penelitian dari Lintangsari et al., (2018) yang menyatakan bahwa di dalam e-money terdapat dana float dan mempengaruhi JUB dalam arti sempit dan Inflasi secara signifikan seiring dengan meningkatnya penyebaran e-money di Indonesia.

\section{KESIMPULAN DAN SARAN}

Berdasarkan hasil penelitian dan pembahasan maka peneliti menyimpulkan beberapa hal yaitu Pada uji $\mathrm{T}$ secara parsial nilai X1 lebih kecil daripada 0,05, sedangkan lebih besar daripada 0,05. Ini dapat diartikan bahwa terdapat pengaruh secara parsial variabel X1 dengan Y tidak berpengaruh, dan variabel X2 dengan Y memiliki pengaruh. Lalu berdasarkan hasil uji $F$ dalam pembahasan, nilai signifikan dalam uji $\mathrm{F}$ lebih besar daripada tingkat kepercayaan atau 0,05. Ini menyatakan bahwa tidak terdapat pengaruh variabel $\mathrm{X}$ terhadap variabel $\mathrm{Y}$ secara simultan, tetapi terhadap pengaruh terhadap salah satu $\mathrm{X}$. Dan hasil dari uji koefisien determinasi menjelaskan bahwa $\mathrm{R}$ Square sebesar 0,843 hal ini menunjukkan bahwa $84,3 \%$ variabel independen yang dapat mempengaruhi variabel dependen, dan sisanya/ $15,7 \%$ dipengaruhi oleh variabel lain di luar penelitian ini.Sehingga dapat disimpulkan bahwa secara parsial hubungan antara JUB dan e-money terhadap inflasi memiliki pengaruh yang signifika

\section{DAFTAR PUSTAKA}

Boediono. (1995). Ekonomi Moneter. In Seri Sinopsis Pengantar Ilmu Ekonomi (5th ed.). BPFE.

Fatmawati, M. N. R., \& Yuliana, I. (2019). Pengaruh Transaksi Non Tunai Terhadap Jumlah Uang Beredar Di Indonesia Tahun 2015- 2018 Dengan Inflasi Sebagai Variabel Moderasi. Ekspansi: Jurnal Ekonomi, Keuangan, Perbankan Dan Akuntansi, 11(2), 269-283. https://doi.org/10.35313/ekspansi.v11i2.1608

Fauzi, S., \& Istanto, L. (2013). Analisis Dampak Pembayaran Non Tunai Terhadap Jumlah Uang Beredar Di Indonesia. Jurnal Ekonomi Dan Keuangan, 2(10). 
Gintting, Z., Djambak, S., \& Mukhlis, M. (2019). Dampak transaksi non tunai terhadap perputaran uang di Indonesia. Jurnal Ekonomi Pembangunan, 16(2), 44-55. https://doi.org/10.29259/jep.v16i2.8877

Hong Z. (2009). The Impact of E-money on the Economy. World Congress on Computer Science and Information Engineering.

Igamo, M., \& Falianty T, A. (2018). The Impact of Electronic Money on The Efficiency of The Payment System And The Substitution of Cash In Indonesia. Sriwijaya International Journal Of Dynamic Economics And Business, 2(3), 237-254.

Lintangsari, N. N., Hidayati, N., Purnamasari, Y., Carolina, H., \& Ramadhan, W. F. (2018). Analisis Pengaruh Instrumen Pembayaran Non-Tunai Terhadap Stabilitas Sistem Keuangan Di Indonesia. Jurnal Dinamika Ekonomi Pembangunan, 1(1), 47. https://doi.org/10.14710/jdep.1.1.47-62

Mahendra, A. (2016). Analisis Pengaruh Jumlah Uang Beredar, Suku Bunga Sbi, Nilai Tukar Terhadap Tingkat Inflasi. Media Ekonomi, 2(1), 1-12. https://doi.org/10.25105/me.v18i2.2251

Sapitri. (2017). Pengaruh Jumlah Uang Beredar terhadap Inflasi di Indonesia Tahun 2013 - 2016. UIN Sultan Maulana Hasanuddin Banten.

Sinaungan, M. (1995). Uang dan Bank (4th ed.). PT Rineka Cipta.

Tambunan, T. T. . (2012). Perekonomian Indonesia: Kajian Teoritis dan Analisis Empiris. Gralia Indonesia.

Widodo, T. (2018). Analisis Pengaruh Electronic Money Terhadap Jumlah Uang Beredar di Indonesia 2009 - 2017. 